\title{
Hand therapy and ergonomics: integration of approaches in vocational rehabilitation and promotion of decent work in Brazil
}

\author{
Thaís Tosetto ${ }^{\mathrm{a} *}$ and Flávia Giuntini Orsi ${ }^{\mathrm{b}}$ \\ ${ }^{a}$ Industrial Engineer Department, Federal University of São Carlo. Rodovia Washington Luís, Km 235, São \\ Carlos, São Paulo, Brazil. \\ ${ }^{\mathrm{b}}$ Department of Occupational Therapy. Centro Universitário Padre Anchieta. Avenida Dr Adoniro Ladeira, 94, \\ Jundiai, SP, Brazil
}

\begin{abstract}
Among the indicators of Decent Work in Brazil, the one referring to the "Safe Working Environment" was the only which had no improvement in the time series analyzed by the International Labor Organisation. There is an increased number of accidents with significant economic and social impacts. Given that many of these accidents involve the hands and cause functional sequels, this paper presents an integration between the approaches of Hand Therapy and Ergonomics in order to facilitate the process of rehabilitation and reintegration, as well as acting to prevent further accidents, thus contributing to the promotion of Decent Work in the country, particularly with regard to safety and health at work and equal opportunities.
\end{abstract}

Keywords: integration, vocational rehabilitation, hand therapy, ergonomics

\section{Introduction}

Several studies $[6,22]$ point to the work as having a central role in the construction of social identity. However, work has as central role as a structuring or pathological element [6]. It is known that the work performed under certain conditions, can cause diseases, shorten life or kill, and can also cause more subtle forms, even invisible, but no less serious, of illness.

The realization of what was prescribed by the organization of work carries a human cost, resulting of utilization of physical and mental that can result in health overload.

The number of occupational accidents in Brazil, with communication of Injury registered increased by $30 \%$ between 1996 and 2007. These data become alarming when extrapolated noting the existence of a large informal economy - it is estimated that about $50 \%$ of Brazilian workers exercise their activities in the informal market - where accidents are not reported, making it inaccessible.

The process of returning to work is a complex situation, involving the individual, company and society [11]. In this context, ensuring equal opportunities for success depends on the success of the rehabilitation process engaged after the accident at work.

This article presents an approach for Health Care Workers, based on the premise of integration between different rationalities in the process of rehabilitation, reintegration, focusing on approaches of the Hand Therapy and Ergonomics.

\section{Decent work and accidents at work}

The concept of Decent Work, developed by the International Labor Organization (ILO) aims to promote access to productive employment and equal

\footnotetext{
${ }^{*}$ Corresponding author. E-mail: thais.tosetto@gmail.com
} 
opportunity backed rights to work, social protection and promoting social dialogue.

The International Labor Conference of 1999 defined decent work as "opportunities for women and men to obtain decent and productive work in conditions of freedom, equity, security and human dignity" [17,18].

In 2008, the ILO Declaration on Social Justice for a Fair Globalization accepts the Decent Work Agenda as the main objective of the ILO's work, whose strategic objectives are to promote (i) the international labor standards and labor rights, (ii) employment opportunities and wages (iii) social protection and (iv) social dialogue and tripartism.

The notion of decent work must be integral, multidimensional and does not refer to the dimension of rights, but also the size of the production context and includes: freedom, equity, security, gender, salaries, etc $[17,18]$.

The indicators proposed by the ILO are grouped under ten key elements of decent work: (i) employment opportunities, (ii) adequate earnings and productive work, (iii) decent working hours, (iv) a reconciliation between work, family life and personal life, (v) work to be abolished, (vi) stability and safety, (vii) equality of opportunity and treatment in employment, (viii) safe work environment, (ix) social security, (x) social dialog and representation of workers and employers.

Among the 10 indicators of Decent Work, the one referring to the "Safe Working Environment" was the only one which had no improvement among the historical series (1992-2007) examined in Brazil by the ILO [18].This fact is supported by studies published by the ILO, whose results show that the Health and Safety at Work, one of the themes of social protection, has often been neglected by governments and social actors. Data show that in 2001 there were thirty million work-related accidents in Latin America. Still, the ILO considers that approximately $10 \%$ of regional GDP is lost due to lack of investment in prevention and that only $1 \%$ to $5 \%$ of cases are reported $[14,15]$

According to Brazilian law, "work accident is the one happened during the exercise of work for the company, causing injury or functional disturbance of a temporary or permanent character." Are also considered work-related injuries: (a) transit accident, which occurred while commuting between home and workplace, (b) the occupational disease triggered by exercise work, and (c) the occupational disease, produced by the special conditions under which the work is done.
The number of occupational accidents in Brazil, registered with communication workers accident, had a 30\% increase between 1996 and 2007 $[14,15,17,18]$.These alarming data become when extrapolated noting the existence of a large informal economy - it is estimated that about $50 \%$ of Brazilian workers exercise their activities in the informal market - where accidents are not reported, making it inaccessible.

According to studies [24], about $35 \%$ of accidents at work involves the hands, the functional impairment causing that hinders the process of reintegration of workers causing social and economic impacts [23].Studies indicates that the functional deficits resulting from trauma to the hand can be both direct and indirect and are represented by disturbances of sensation, joint motion, deviations of association and segmental lesions [10,19,24].

In addition to physical disorders, the accident also involves a psychic and a social dimension, given the centrality of work in the construction of social identity. The functional rehabilitation ergonomics coupled with aims to facilitate the process of vocational rehabilitation and contribute to the development of Decent Work.

At first, the patient must go through the process of physical rehabilitation, with emphasis on hand therapy, focusing on increasing muscle strength, range of motion and coordination. However, this alone does not process the Ensure the effective reintegration of the worker. This approach must be accompanied by analysis of the activity to be performed when returning to work whether or not there is residual deficit. the ergonomic work analysis has dual importance in this process: (a) must identify potential risk situations that led to the accident to prevent further develop improvements and occurrences, and (b) identify the organizational fit, the physical and cognitive requirements to be held on return to work, indicating whether they are compatible with the type of lesion or with limited physical capacity and psychosocial characteristics. Given the complexity of the process, other rationales should also be involved, such as physiotherapy, occupational therapy, psychology and social work to promote the comprehensive care. 


\section{Hand therapy and upper limb rehabilitation: evaluation and treatment}

The hand is the functional and final extremity of the upper limb, therefore, plays an important role for humans in carrying out daily activities, whether in daily activities, leisure and labor $[1,3,4,9,10]$. This constant demand is correlated to the high rate of injuries of the hand [24]. The accident at work involving the upper limbs in the literature is related to the need for frequent use of hands and the difficulty of the worker to protect them without causing impairment in the ability and preventing the decrease in productivity.

Any changes that may occur in hand function, either by traumatic injury or illness results in functional imbalance, causing the individual, temporarily or permanently to adapt/ re-adapt to productive actions [21,24].

Based on the knowledge of anatomy, physiology and biomechanics the hand and upper limbs therapy develop their practice with patients with diagnoses of trauma, osteoarticular sequels, and neuromuscular diseases of the hand. To this end, it has a series of protocols and mechanisms for evaluation and treatment in order to restore hand function and develop the potential of the individual who is unable to produce.

The process of care begins with the evaluation of hand function. The assessment includes tests and muscle function, range of motion, muscle strength and sensitivity will provide the basis of the treatment plan.

Three types of appraisal are recommended to get an accurate idea of the degree of disability resulting from injuries to the hand: anatomical, functional and aesthetic [3]

Depending on the time of intervention, treatment may be conservative, preoperative, postoperative and early treatment, based on knowledge and analysis of the field of human activity.

Treatment plans aim to remedy or minimize the changes in sensitivity, range of motion and strength, within the limits and when there is residual sequels. Periodic reassessment guides the therapeutic process, as well as defines the end of the period of rehabilitation $[4,9,10]$.

However, stabilization can occur with significant functional limitations that difficult the process of reintegration of the worker, in the extent that limits or even prevents the implementation of certain activities. At this point, the identification of assistive technology or potential adaptations in the workplace is fundamental to facilitate reintegration.

\section{Ergonomic analysis and rehabilitation at work}

The Ergonomics was born of a fundamental discontinuity between task and activity [13]. Authors define tasks and activities through three distinct categories: the prescribed task, the effective task and activity. The prescribed task is defined by those who design the work system in terms of goals and objectives to be achieved and the conditions for implementation through the establishment of routes of operations. The effective task consists of targets and rules from the prescribed task, however, changed once in practice, to perform the task if the subject changes some rules while creating others, resulting in the task actually performed by the individual [20]. The activity is all that the subject "does" or "think" to perform the prescribed task. What the subject does, makes up the "activity" and that the subject thinks, makes up the "cognitive activities" [7].

The work is a concept embodied in a body, registered in temporality and context [8]. For the authors, the work activity appears inseparable from a three-dimensional relationship that the individual has with the sociotechnical context. A committed relationship with the production or performance of services to achieve specific results, a relationship with the self to create and manage the changing needs of the body, reason and affection, and a social relationship with others.

Given the gap between task and activity, manifested in productive situations, the Ergonomic Analysis of Labor has a fundamental role in the process of vocational rehabilitation and reintegration into work, as it allows us to identify the determinants present in work situations.

Ergonomics is supported by two key intentions: on one hand, produce knowledge about the work on the conditions and the relationship of man to work; another, forging knowledge, tools and principles susceptible rationally guide the action of the transformation of working conditions in order to improve the relationship between man and work [5].

To understand the determinants of work situations the Ergonomic Analysis of Work has as basic assumptions the distinction between prescribed work and real work, the variability of contexts and individuals, the concept of work load and regulation [2]. These four basic concepts should permeate the 
whole process of analysis-synthesis. Based on the identification and consideration of these concepts the work situation studied, criteria for projects that include health and productivity can be developed.

The identification of the logic of activity opens up possibilities for intervention in Occupational Health.On one hand, it allows actions to be taken so that accidents do not happen again and contributes to the promotion of a safe working environment. On the other hand, it allows to correlate the job requirements in terms of physical, cognitive and organizational to the limitations and potential of individuals.Still, identifies changes to be implemented to promote the reintegration.

In the context of vocational rehabilitation, besides promoting the knowledge of the work, the Ergonomic Analysis is a crucial moment, for extrapolating the walls of the clinic and is part of the real work situation.

\section{Integrating approaches}

The paper presents an approach of integration between the Hand Therapy and Ergonomics of the complementary and essential in the process of Vocational Rehabilitation.

The vocational rehabilitation process can be characterized by three key moments, here called (a) Screening and Assessment, (b) Health Care and Rehabilitation Strategies and (c) Return to Work.

Every moment is intended to structure the support network necessary for the vocational rehabilitation process. Thus, the initial moment is characterized by multi-evaluation of the patient. It consists of medical opinion and assessment professionals involved in physical and psychosocial rehabilitation and may include professionals in occupational therapy, physiotherapy, psychology and social work. The integration between the professionals can take place within a single structure or be accomplished through partnerships and referrals to local public health.

In this phase, the identification of service priorities is essential. A well-designed evaluation will determine the prognosis and effect the necessary referrals, which will start the physical and psychosocial rehabilitation.

As reported, a significant proportion of occupational accidents resulting in injuries of the upper limbs demand a specific intervention in Hand Therapy, the focus of this work. Orthopedic disorders and/ or associated neurological disorders may require referrals to specific areas of occupational therapy and physiotherapy.

However, it is known that accidents at work, and physical trauma, can lead to various psychosocial disorders and require equal attention in order that rehabilitation process has a greater chance of success.

Identified psychological demands, the worker is referred for evaluation in psychology and behavior, seeking to strengthen him psychologically to return to work.

Data show that about $50 \%$ of the working population in Brazil is inserted in the informal labor market and therefore are not eligible for pension benefits. Given this reality, financial difficulties may also be present and influencing the treatment process.Social services are essential for evaluation and possible award of benefits and inclusion in government social programs.The economic and financial support will enable the required frequency of attendance at meetings and provide the minimum requirements to keep the patient and his family.

The physical and psychosocial rehabilitation has an indeterminate duration and will vary with the pathology, the degree of functionality and psychological demands involved.

The functional rehabilitation, especially expressed here by the Hand Therapy, finds its limits in terms of functional gain. Sequelae may be present making it impossible to return to work to a greater or lesser degree.

This is where the ergonomic approach, represented here by the methodology of Ergonomic Analysis, it is essential for assessing the adequacy of the proposed activities for the workers and their real abilities and functional skills.

Given the distance between prescribed work and real work, the Ergonomic Analysis will identify the determinants of work situations and the skills required in the exercise of the activity. That is also when the intervention and the rehabilitation process go beyond the walls of the clinic and have their focus to real work situations.

The more quality on the development of the Ergonomic Analysis, the greater the chances of success when they return to work.It is noteworthy that the approach is not restricted to the analysis of activity, but encompasses the whole organizational context that circumstance.

If the correlation between the proposed activities and functional capacity of the worker is positive, the return to work in the same function is possible. On the other hand, if the correlation is negative, the possibilities of using assistive technology and / or 
adaptations in the workplace are evaluated and that may enable a return to the same function. Even if there is no possibility of using assistive technology and / or the development and deployment of changes at work, referrals to retraining becomes necessary to develop new skills, such as increasing the level of education or learning a new role.

The rehabilitation should be based on individual aspirations and abilities and the functional restrictions. In such cases, return to work should take place in another function, whose requirements are compatible with the skills developed.

The approach presented, expressed by fluxograma1, however, is not a linear path to be followed, but serves as a guide for the rehabilitation process and therefore should be adjusted to suit the particular situation of each.
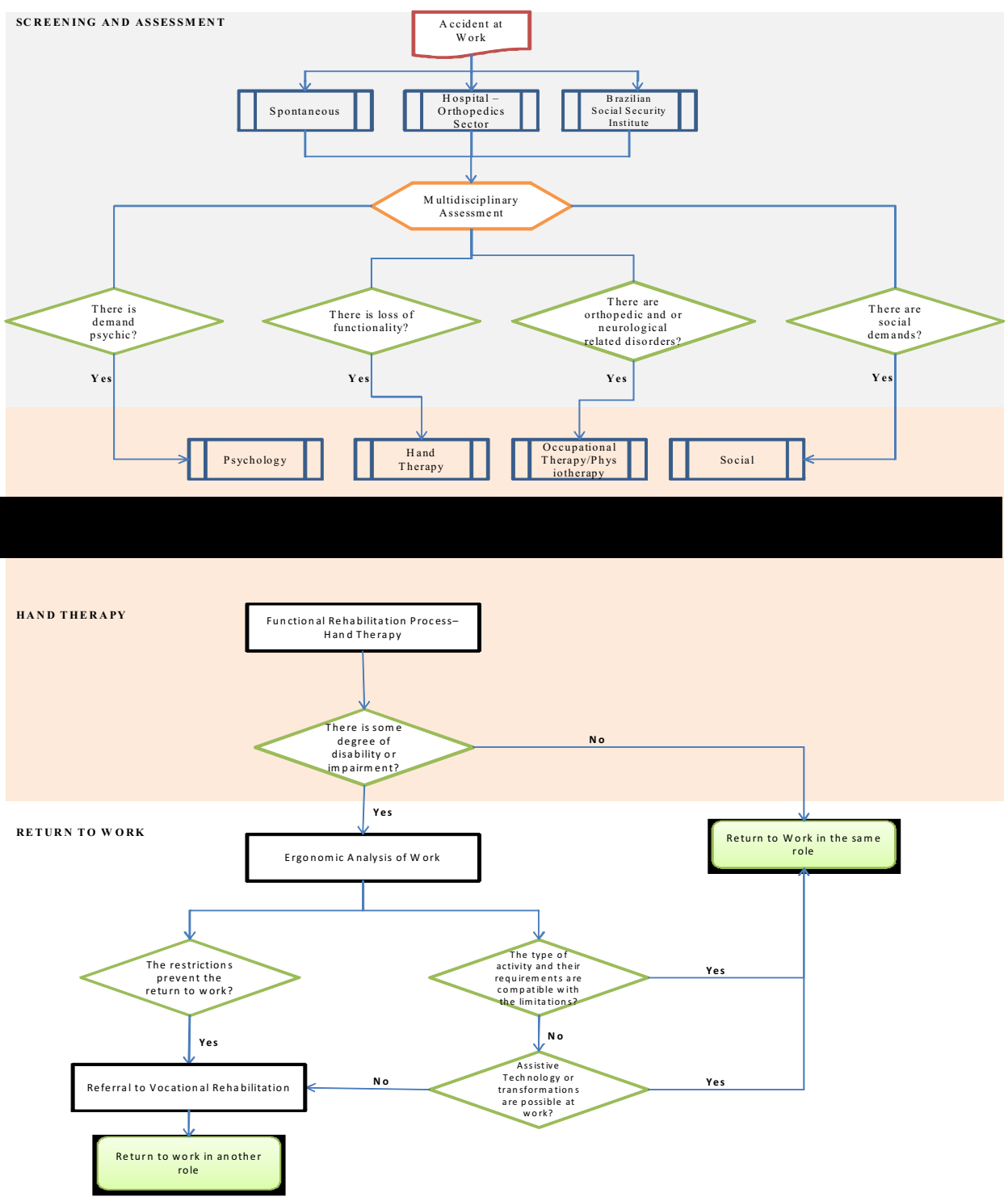

Figure•1. Integrating Approaches 
Note: This approach of attention to the Occupational Health, based on the integration between the rationalities of physical rehabilitation, with emphasis on the approach of Hand Therapy, ergonomics and psychosocial is implemented by the authors, through a partnership between the Health Clinic Centro Universitário Padre Anchieta, the Brazilian Social Security Institute and St. Vincent's Hospital, through residency in orthopedics at the Faculty of Medicine of Jundiaí. Preliminary results are under analysis.

Patients usually are referred by the orthopedic clinic of the hospital or rehabilitation professional staff of the INSS. There are also spontaneous, especially in the informal sector who do not have any social security benefit. The attention is free to workers and seeks their reintegration into the labor market as best as possible, given the centrality of work in the construction of identity.

\section{Final considerations}

Given the complexity of the work, and its centrality in the construction of social identity, the process should seek to integrate vocational rehabilitation with the aim of integrality of action. The reintegration process can have a greater chance of success when incorporating ergonomic work analysis through disclosure of the logic of activity.

The construction of the health care for occupational health in Brazil still depends on the implementation of effective public policies, to monitor and adapt to the changes brought by capitalism. It is necessary that the rights at work are met and enforced and that various sectors come together to develop strategies to assist businesses to the promotion of Decent Work.

\section{References}

[1] Abdalla, L. M.; Brandão, M. C. F. Força de preensão palmar e digital. Sociedade Brasileira de Terapia da Mäo. Recomendações para Avaliação do Membro Superior. Säo Paulo: SBTM, 2003.

[2] Abrahao, J. I; Pinho, D. L. M. Teoria e prática ergonômica seus limites e possibilidades. In: Maria das Graças Torres da Paz; Alvaro Tamayo (Org.). Escola, Saúde e Trabalho: estudos psicológicos, Brasília: Editora de Brasília, p. 229-240, 1999.
[3] Araújo, P.M.P. Introdução à avaliação de membro superior. In: Sociedade Brasileira de Terapia da Mäo. Recomendações para Avaliação do Membro Superior. Säo Paulo: SBTM, 2003.

[4] Cavalcanti, A; Galvão, C. Terapia Ocupacional: fundamentação e prática. Ed. Guanabara Koogan, 2007.

[5] Dejours, C. Epistemologia Concreta e Ergonomia. In: Daniellou, F. (org). A ergonomia em busca de seus princípios: debates epistemológicos. São Paulo: Edgard Blucher, 2004.

[6] Dejours, C; Abdoucheli, E. Psicodinâmica do trabalho. São Paulo: Atlas, 1994

[7] Falzon, P. Os objetivos da ergonomia. In: Daniellou, F. (org). A ergonomia em busca de seus princípios: debates epistemológicos. São Paulo: Edgard Blucher, 2004.

[8] Ferreira, M. C; Dal Rosso, S. O sujeito forja o ambiente, o ambiente "forja" o sujeito: Mediação indivíduo- ambiente em ergonomia da atividade. In: A regulação social do trabalho. Brasília: Paralelo, 2003.

[9] Ferrigno, I.S.V. Terapia da Mão. São Paulo: Santos, 2007.

[10] Freitas, P.P. Reabilitação da mão. São Paulo: Atheneu, 2005.

[11] Gravina, M. E. R., Nogueira, D. P.; Rocha, L. E. reabilitação Profissional em um banco: facilitadores e dificultadores no retorno ao trabalho. Revista de Terapia ocupacional da Universidade de são Paulo. V.14., n.1., pp. 19-26, 2003.

[12] Guérin, F.; et al. Compreender o trabalho para transformá-lo: a prática da ergonomia. São Paulo: Edgard Blucher, 2001.

[13]Hubault, F. Do que a ergonomia pode fazer a análise?. In: Daniellou, F. A Ergonomia em Busca de seus Princípios: debates epistemológicos . São Paulo: Edgard Blücher, 2004.

[14] OIT. Agenda Nacional de Trabalho Decente. Brasília, 2006.

[15] OIT. Trabalho decente nas Américas: uma agenda hemisférica 2006-2015. Brasília, 2006.

[16]OIT. Declaração da OIT sobre os princípios e direitos fundamentais no trabalho e seu seguimento. Brasília, 2007.

[17] OIT. Emprego, desenvolvimento humano e trabalho decente: a experiência brasileira recente. Brasília (2008).

[18]OIT. Oficina de Consulta Tripartite sobre Indicadores de Trabalho Decente para o Brasil. Brasília, 2009.

[19]Lech, O. Princípios básicos. In: Pardini, A. G. Cirurgia da mão: lesões não traumáticas. Rio de Janeiro : Medsi, p.1-33, 1990.

[20]Leplat, J.; Hoc, J. M. Tâche et activité dans l'analyse psychologique des situations. In : L'analyse du travail em psychologie ergonomique. Leplat, J. (Coordinateur). Toulouse: Octares, 1992.

[21] Mattar Jr, R.; Azze, R.J. Atualização em traumatologia do aparelho locomotor. São Paulo: Instituto de Ortopedia e Traumatologia da Faculdade de Medicina da Universidade de São Paulo, 2000.

[22] Morin, E. M. Os sentidos do trabalho. In: Wood, T. (org.). Gestão Empresarial: o fator humano. São Paulo: Atlas, 2002.

[23] O'Sullivan, M. E.; Colville, J. The Economic Impact of Hand Injuries. The Journal of Hand Surgery. European Volume. vol. 18, n. 3,pp. 395-398, 1993.

[24] Pardini, A. G. Lesões da mão em acidentes do trabalho: análise de 1.000 casos. Revista Brasileira de Ortopedia. v. 25, n.5, maio, pp. 119-124, 1990. 